This article was downloaded by: [University of Sydney] On: 14 March 2015, At: 01:49

Publisher: Routledge

Informa Ltd Registered in England and Wales Registered Number: 1072954 Registered office: Mortimer House, 37-41 Mortimer Street, London W1T 3J H, UK

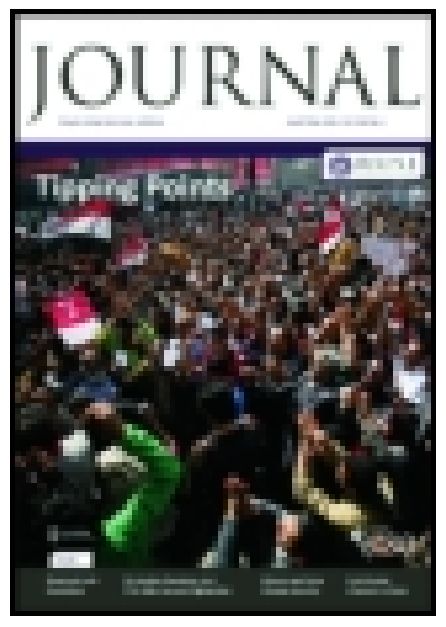

Royal United Services Institution. J ournal

Publication details, including instructions for authors and subscription information: http:// www. tandfonline.com/ loi/rusi 19

\title{
Present Position of the Armour Question
}

Captain C. Orde Browne ${ }^{\text {a }}$ a late Royal Artillery, Lecturer on Armour Plates, Department of Artillery Studies, Woolwich Published online: 11 Sep 2009.

To cite this article: Captain C. Orde Browne (1884) Present Position of the Armour Question, Royal United Services Institution. J ournal, 28:123, 107-126, DOI: 10.1080/03071848409430449

To link to this article: http://

dx. doi.org/ 10.1080/03071848409430449

Taylor \& Francis makes every effort to ensure the accuracy of all the information (the "Content") contained in the publications on our platform. However, Taylor \& Francis, our agents, and our licensors make no representations or 
warranties whatsoever as to the accuracy, completeness, or suitability for any purpose of the Content. Any opinions and views expressed in this publication are the opinions and views of the authors, and are not the views of or endorsed by Taylor \& Francis. The accuracy of the Content should not be relied upon and should be independently verified with primary sources of information. Taylor and Francis shall not be liable for any losses, actions, claims, proceedings, demands, costs, expenses, damages, and other liabilities whatsoever or howsoever caused arising directly or indirectly in connection with, in relation to or arising out of the use of the Content.

This article may be used for research, teaching, and private study purposes. Any substantial or systematic reproduction, redistribution, reselling, loan, sub-licensing, systematic supply, or distribution in any form to anyone is expressly forbidden. Terms \& Conditions of access and use can be found at http://www.tandfonline.com/page/terms-andconditions 
Fridey, Febrúary 8, 1884.

Vice-Adyiras H. BOYS, Mrember of Conncil, in the Cl

\section{PRESENT POSITION OF THE ARMOUR QUES'}

Bj Captain C. Orde Browre, lato Rogal Artillers, Lec Armonr Plates, Department of Artillery Stadies, Wools

Tre chicf object of this paper is to call attention to featur present position of tho armour question that appear to bo pec of great importance. In support of tho data on which sacl sions are based, I proposo to gire, as bricfly as possible, tho: certain experiments conducted during 1882 and 1883, distio as in provions papers betwecn the effects produced on soft anc armour. Bg soft armour I mean armour which yiclds by pei By hard armour such as camnot be perforated and is dest breaking up.

Tho experiments I propose to notice aro: (1) Krupp's trisls; (2) tho Italian Spezia plato exporiments with tho 100. at the end of 1882 ; (3) the trial of compound and steel ] St. Petersburg, at tho end of 1882 and the commencement ? and (4) the enginecr plato experiments at Shoebargness in and September, 1883.

Krupp's Meppen plate trials took placo in March, 1882. T sisted wholly in trials is to tho perforition of soft armor directly or obliquely. $\Delta 5 \cdot 9$-inch gan was fired trice at $t$ r plates of wronght iron with 10 inches of wood in between. Tha represented on the dingram" (P1. I, Fig. 2, " horizontal section, "front riew,"). The shot weighed $109 \cdot 6 \mathrm{lbs}$. (49.7 kg.). ? wias fircd with a charge of $39 \cdot 68 \mathrm{lbs} .(18 \mathrm{~kg}$.), and tho second $(17 \mathrm{~kg}$.). The sccond ono had a relocity of 1,750 feet, its energy was 2,328 foot-tons, and it had sufficient work to har trated 11.65 inches of iron in one thickness, or I suppose 12 inches of iron in two thichnesses. It went thronglh th target and passed on up tho rango 328 yards uninjured. Tl be accounted for by the circumstanco that the rood betw plates was mach too thick. The plates wero good, but if t1 is safficiently thick to allow the point of tho projectilo to get

1 The figures hare been photographed from blocks kindly lent by the the "Engincer," in which paper reporta of tho trials appeared. 
the bent and broken edges of the front plate before it meets the hinder. one, theu the maximum resistance is not offered by the plates. Experiments at Shoeburyness established the fact that the best thickness was somewhèro about 5 inches, which prevents one plate jarring on the other, and yet does not allow the projectile to get clear of the broken pieces of one plate before it comes to the second one. In that way I understand Colonel Inglis to expect that this shot thus fired might get fairly through these plates. That Krupp's projectiles did more than this may be perhaps owing to their excellence.

The second experiment was one of oblique fire (vide Pl. I, Fig. 6). The same gun was fired at an angle of $35^{\circ}$ on the normal, or $55^{\circ}$ with the plate, against a plate $7 \cdot 9$ inches $(20 \mathrm{~cm}$.) thick, with a backing of 9.84 inches of wood, and 0.98 inch of skin. Two rounds were fired with charges of $39.68 \mathrm{lbs}$. and $37.5 \mathrm{lbs}$. The latter gavo to its projectile a striking velocity of 1,750 feet. It had sufficient work to have penetrated $9 \frac{1}{2}$ inches at the striking angle, supposing the projectile to "bite" properly; but at so oblique an angle it has been found that the projectile has to be more than a match for the plate, generally speaking, to bite, and therefore the penetration was unusually good.

There were other incidental featares in Krapp's trials worthy of notice. For example, ho tried common shells made of steel, tho object being to get a thinner shell with a larger bursting-charge, or, on the other hand, to make a shell with a much stronger envelope, so that there shonld be greater resistance when the shells burst. In some experiments-the "Shannon" trial for one-shells bave broken up instead of bursting inside the plates at which they wero fired, and the result has been but small. Thus there is an advantage in having a strong envelope : or, of course, the advantage may be taken another way, by having a very much larger charge-how rery much larger you may see from the fact of a long 8.27-inch "torpedo" shell containing 106 lbs. of powder. You can hardly conceive of a shell 81 inches in dinmeter containing $106 \mathrm{lbs}$. kursting-charge. This, no doubt, is a feature which must receive great attention at some timo in this country.

The Spezia trials of last November were made as to hard armour, and consisted in trials of compound plates that were ordered for the "Italia" from MIessrs. Cammell, in competition with other" compound plates from Sir Joln Brown and Co., and steel plates from M. Schneider. The dimensions of all were the same-18.9 inches thick, 10 feet 10 inches long, and 8 feet 7 inches wide (vide Pl. II, Figs. 1 and 2, for section). Cammell's plates had steel faces made on Wilson's patent, and Brown's plates on Ellis's patent, the back of cach boing wronght iron, and the front, for about one-third the thickness, stcel. The componnd plates had somewhat harder steel faces, laving raiher more carbon in the steel than in Schneider's steel plate, which was entirely of steel containing about 0.45 per cont. of carbon. It was not rolled. It was made from a very large pile 7 feet thick, hammered down to 19 inches thickness under a 
inportant then to poto that that. Tas the was in which the were made. Schneider's target was held up with twenty the others with six bolts each only. They fired, as they alw Spezia, precisely similar ronnds at each target one after rising the 100-ton muzzle-loader. The first round was fired wit of $328.5 \mathrm{lbs}$. and a $2,000 . \mathrm{lb}$. shot at a low relocits of about: thus redaced so as to be something under a match (on th tion baso of calculation) for tho target. Its storcd-up . 20,710 foot-tons. It was capable of penetrating about 19 . of iron, that is to say, it was a match for tho thickne target had the target been iron. Of course, ench target $\mathrm{b}$ pound metal, it onglit to hare been equal to about 5 inches $)$ is, to about $24 \frac{1}{2}$ inches of iron, and the shot was therefore nc for it in penetration. Tho first shot being fired at Camm (ville Pl. II, Fig. 1), the bead was buried in it, and the which you seo upon the diagram were made, tho corner tached. A similar round mas fired at 13rown's, only that was a great deal less (ville Pl. II, I'ig. 6) ; and at Schnc shot lodged apparently without tho slightest crack anjw Pl. II, Fig. 5).

The nezt round was fircd at cach with a charge of 478.311 sufficient work to perforate the targets; that is to say, the cnough mork in it to penetrate 24.7 inclies of iron. The $f$ so fired had 1,545 fect striking relocity, intended to be cq think, to the perforation of 19 inches of compound armour. 'I up work was 33,100 foot-tons. The effects produced are she diagram. Cammoll's plate was brokon up into four or fice I. Pl. I, Fig. 14). The wholo plate was brought down, the bi way. If you assembled the pieces, they would have the form $r$ in that diagram (Pl. II, Fig. 15). In the samo way a sho at Brown's plate and brought down part of the target: remained, hanging by a bolt (vide $\mathrm{Pl}$. I, Fig. 12). The are shomn assembled in PI. II, Fig. 13. The second round at 5 produced the effect shown in PI. II, Fig. 7. Of course, th difference between those results is very great, and is mai the fact that Schneider's target is held up by bolts; . Thereas targets not being sufliciently bolted fell on the ground, but less, Schneider's plate held. better. Tho cracks are pecu not think they show the sume complete fractures as the oth you had looked at the section of the iron you would have the stcel had a fibrous tough look about it. They then fis projectile, thought to be a Whitworth. It had a striking 1,538 feet and about the samo stored-ap work as be 34,080 foot-tons-about a match in penetration for the great piece of stecl was brought down, the projectile was fla bounded back, the top frame round the target was thro front so as to orerhang the face (vide Figs. 19, Pl. II, and Part of the plate was driven into the back and part bro 
with the shot, which rebounded and lay in front (Pl. II, Figs. 20 and 23). An inspection of those pieces of plate would give you tho idea of its being remarkably good metal (vide P1. II, Figs. 21 and 22). It was afterwards stated that tho projectile was not a Whitworth's shot, but one of Terre-Noire manufacture, and sent in mistake for a Whitworth.

One moro ronnd was fired. Of course the plate was getting. demoralized, and it is hardly worth looking at tho result in Pl. I, Figs. 25 and 26. The projectile was a San Vito cast steel shot, and that projectile broke up in a very different way to tho Iast montioned. The head appeared good, but the body bad: the difference being accounted for by tho head having been tempered in oil.

The St. Petersburg experiments began almost on the same day, and were carricd on as a competitive trial between Cammell's steel-faced and Schneider's steel plates. In each case, tho first shot fired was the heaviest. An 11-inch breech-loading gun was fired at 12-inch plates, 8 feet by 7 feet, and the striking velocity of the first round was 1,506 feet, the charge being $132 \mathrm{lbs}$. English : the weight of the shot was $553 \frac{1}{2}$ lbs., the work in the shot was 8,704 foot-tons, and the power of perforation equal to about $16 \cdot 3$ inches of iron-just about a match for the target. The first round fired at the Schneider plate cracked and broke it, as shown in Pl. I, Fig. 1. The next was fircd with $81 \mathrm{lbs}$. of powder, a striking velocity of 1,167 feet and 5,228 foot-tons work (Pl. I, Fig. 2); it struck it with a power of perforation of 12.21 inches of iron; and the third, with the same, broke a quarter of it away (Fig. 3, P1. I). The Schneider plate again was bolted up with a great many bolts, whereas the Cammell had only four bolts. The first round being fired at the Cammell plate with a charge, \&c., corresponding to the first round at the Schneider, the projectile of conrse broke up, as in tho provious rounds. Tho head remained embedded in the plate, and very slight cracks were made (Pl. I, Fig. 4). The next round, fired with a charge, \&c, as in the second round at the Schneider plate, detached the plate, which fell on its face. Then it was picked up surface injuries were found to have been produced. The steel-faced plates are apt to have more or less concentric cracks; while, as far as my exporienco goes, concentric cracks are not produced on a steel plate, but, on the contrary, all the cracks are radial. Then they mounted the Cammell again and fired at it, with the same reduced charge, with the same sort of effect, until they eventaally got four shot planted on it, and obtained the result shown in Pl. I, Fig. 3A, parts of the face being scaled off; but tho plate holding together and having a good deal of rork left in it.

In this case there is no doubt the Cammell compound plate has beaten the steel plate; but in the case of Spezia the steel was the better of the two. There is little doubt that at Spezia Schneider's plate was specially made for the programme of experiments, The Cammell plate was supposed to be a sample plate, exactly corresponding to those that would go on the "Italia."

On Tuesday, Angust 22, 1883, an experiment of great interest, especially to England, took place at Shoeburyness. It was carried 
naturo of the work tested is shown in the accompanyin; (Pl. III, Fig. I).

The shiclds fixed on the face of Portions II and III aro $\varepsilon$ that on No. III, against which the first shot was to be firet of two plates of 8 inches thickness each, of wrought is wicleed with 5 inches of wood behind each, mado up of 1 nesses, that is, $2 \frac{1}{2}$-inch planks laid horizontally, noxt be. plate, and $2 \frac{1}{2}$-inch planks behind them placed rertically Fig. 9). The dimensions of each plate were as follow 12 fect, Leight 7 feot, and thickness 8 inches. They were by Messrs. Cammell. They wero lield in their place by six bo Palliser English system.

Tho shicld on Portion II consists of 12 inches of Wilso faced iron, in a plato 7 feet by 7 feot held up by four bc inside an iron frame, as shown in Figs. 1 and 2. On the $t$ work was laid a quantity of old broken plating, to kecp the and concreto from rising under the force of tho blow-(vid at Portions II and III. Stractures of concroto would har their full strength for many months, porhaps years to come, must allow for this in this trial, which it will be seen was a vt one.

The gan cmployed was the 80-ton gan, M.L., which was at 200 yards distance. Ono round was fired from it at Port irou sandwich on granite. A projectilo weighing $1,700 \mathrm{lbs}$. with a charge of 450 lbs. of pobble powder, with a re 1,588 feet. This implies a total amount of stored-up work 29,730 foot-tons, or 594.4 foot-tons per inch circumferenc senting a power of perforating about 25 inches of iron. was a servico Palliser chilled iron projectile, aboat 3 feet $\varepsilon$ long, fired withont bursting charge; the radius of tho he: about $1 \frac{1}{2}$ inches diameter. Tho shot struck a point 3 feet bottom of the plate, and 3 feet 8 inches from tho left end lc it. The effects were as follows:-Tha shot cut a clean hole throngh both plates, and breaking up during penetration rather to the left, the point reaching a depth of nearly measuring from tho front faco of tho iron. Tho plates admirably, the hole being cat almost without any apparent the surrounding portion of tho plate. The rood was driven 0 : 5 inches of the ends of the horizontal planks being thrust ou the plate at the loft end, and 3 inches on the right. Tho gra palverized all round the projectile for some distance. Crac visible in the granite in front, as shown in Fig. 8. They obscrved to radiato from the point of impact, speaking $\mathrm{g}$ ، The stones of the courso through which the shot passed are, layers of wood, forced longitudinally, left and right, projecting beyond the other at cach end of the squares of masonry, One or two cracks also were visible in the brickrork linine small cross passago belind the part struck. The bolts do no 
A velocity of 1,100 feet ought to be sufficient to enablc jectile to perforate 16 inches of iron alone.

England is the only Power that has employed wrought is considerable cxtent in coast forts, chilled cast iron havin! generally abroad. An experiment, therefore, that shows tha iron behares weil is specially satisfactory to us as a $n$ i surely this is the case here. The iron has offered a $\mathrm{gr}$ ance, and it has suffered only locally. The latter is, important as affecting the further powers of resistance of A shield to resist repeated blows of the 80-ton gunshot mus1 be exceptionally strong. When it fields it yields locally, $z$ still a good front protection.

The second round was fired on September 11th at Port steel-faced plate, \&a. The projectile was in this, and in e case, a Palliser shot. weighing over 1,700 lbs., the strikir. being something under 1,600 feet. The effect is seen in and 5 , which show the plate, and in Fig. 2, which shows th behind it. It will be seen that the plate stood wonderfully. shot broke up, its head being fixed in the plate. (See Figs 5.) The plate was bent and bulged, the bulge and shot bei unusually flat against the masonry supporting the plate. ? great annular rents immediately round the shot, where mi work must have been done, the radial cracks were nearly a cracks-the depth of the most important may be seen in Fi bolts stood well, holding the plate up. They were subseques to enable the back of the plate and masonry to be examint shows the granite with the indentation and cracking $\mathrm{m}$ : blow. This, it may be seen, is very slight, the deepest im that made by the shot point at $A$. T'he spring of the opened the joints at the upper bolts $B$ B, and if the side vir be examined, it will be seen that a tremendous strain fallen on these bolts. Crack $\mathrm{C}$ was produced by the first $]$ at Portion III. Hence the cracks in the masonry, as bef all radiate from the point of impact.

Taking this round as nearly the same as No. 1 , wo $\mathrm{m}$. about 30,000 foot-tons work have been delivered on this that a compound 12-inch plate has, under the conditions borne the blow of a shot capable. of perforating about 2 : iron.

How is this to be accounted for? The natural sugg inferiority in shot, special excellence in plate, or special su] to this nature of plate by hard backing. There does not a any reason to call the shot bad. The plate is certainly ex probably the last-named canse told most-that is to say hard backing specially brings ont the powers of steel-ft This supports the opinion of the Italian Committee, who that the jielding backing at Spezia told much more : compound plate than the steel. Anyone who looks at th 
judge what wonld hare been the effect on this plate if $t l$ had allowed it to bend much more. Would not the line from the point of the shot to the cracks about $A$ hare been $c$ The balged lack of the plate and the shot hare received dous pressure agninst tho backing. Can wo doubt that if $t]$ bad not been an extraordinars ono the plate mast hav across? I am in no way detracting from the qualities of which is apparently beantiful. It would, however, surely sible for any 12-inch plate to stand the blon we have t, under any ordinary conditions. Giving it all credit for , then, we have to explain why it bore much more than twic that would generally smash such a plate up. I soggest the : The plate with its hard surface and hard backing resistec very sharply and rigidly; this, being a chilled shot, broke $x$ a slock much more easily than a good stcel shot rould do under these particular conditions, a softer shot with mor might have done better. Still, an enormons force was breaking and foring out rings of metal close cound the actually crushing in the face of the granite bohind it, and i noticed that there are no detached bruises on the plate fac the work was delivered well at the point of impact. The been cracked from the front to a depth of $9 \frac{1}{3}$ inches at thi shorn in Fig. 3, but the shot was anable to bend it back open the remnining thichness from the opposite side, and so was borne.

To come now to the features in the quesiion that may app for special attention. First our system of calculating effects.

I think the table herewith will sbow that in Eugland, in R in Italy the blow is estimated on the basis of the power of $t$ ] perforate. In the case of wrought-iron armour this is un correct, but this table shows cases of steel-faced plates wher tion was not effected, but whero the action was more nearl fracture by an ogival-pointed medge striking the plate and si before many inches of the wedge had entered it. The effe probably be proportional to the total energy of blow deliver wedge, that is the shot, but withont roference to the fall di: the shot, for that never comes into the question.

Perforation is calculated by dividing the stored-up work $c$ either by the area of the cross section or else by the diameter of Either plan in a modified form is correct where the shot mak whose size depends on its diameter. A shot of small diameter requires less energy to makes its hole than a larger one, and proportionately; but in hard armour, when both of them their points into the plate before fracture occurs, it is diffict bow the small diameter gires nny sensible advantage to a proje this objection is pressed, it is often admitted to be correct, yet remains that the system of calculation just condemned is the

PUL. XXFIII, 
power to perforate wrought iron of the same thickness pound plate attacked (vide table, at Shoeburyness, St. Petersbarg.) On the higher standard the shot has suf trating power to perfornte a wrought-iron plate of per] cent. more thickness than the compound plate attacked Shoeburyness, Spezia, and St. Petersburg). In many cas lead to passable conclusions, but it depends on certain relat and plate being maintained. Cases may arise when it roul wrong. For example, at Coponhagen, a 9-inch Woolwich $5 \frac{3}{4}$-inch Krupp were fired in comparison; the former had 1 energy per inch circumference, the latter 123. Their would therefore be nearly the same, but their respective er 16,403 and 5,760 foot-tons. It would be unreasonable to $s$ the latter, with little more than one-third the energy of would smash up hard armour to the same extent simply on that, if holes were made by each shot, this would only' nef hole, when as a matter of fact no holes could bo made.

I have here a simple kind of drop to illustrate this poi my request in the Royal Laboratory, Woolwich. I have t Director of Artillery for having decided that it should Government expense. It would be -very dangerous to atten questions of impact by a toy like this, where the velocities sarily only those of a small fall and the substances are ingly fragile. We muy, bowever, get illustrations which tions clear and impress facts on our mind, and there probability that the laws governing impact at high vel apply to these low ones; nay, the machine could only be m assumption, and any correct results must be due to $\mathrm{ph}$ which bear out the assumption. You will observe that advantage of great simplicity. Having the stored-up work form of $\mathrm{WH}$ (weight with height), instead, of $\frac{\mathrm{W} v^{2}}{2 g}$, wo gel square in the formula, and the ealculation of effect is ind On the perforation system the diameter varies with the hei the weight being kept constant, the ${ }_{4}^{1}$-inth bullet-punch; of 1 foot, ought to hare the same punching power as the about 2 feet, and the 1-inch with about 4 :feet drop. Thu board-can be perforated by the 1:inch bullet-punch wit 60 inches, while the $\frac{1}{4}$-inch bullet perforates it with a fall of 15 inches, bat about 17 -inches, this small atrop giring the of perforation to the small ballet as the higher one does t bullet. As regards perforation, then, through soft material, equal ander these conditions. But now let me substitute.a he that yields by fracture rather than perforation. The smaI wreaks it at 9 inches fall; the 1-inch ,bullet has the same

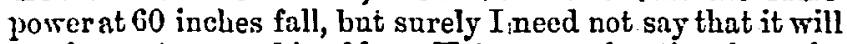
uuch greater smashing blow. iYet onr perforating formula 
This is a gross case. I take it, to illustrate the error in $t$ Probably in no case has the system been applied when a $v$ crror has been caused, but the system is wrong for hard ar: in a greater or less degree, must give wroug results.

It is eusier to say this, howerer, than to suggest a rig. The physical conditions are diffeult to deal with. How can late the work necessary to make a crack ? Tho commence crack certainly represents more work than the completion. we arrive at the number to be made? Then while length makes it harder to crack it longitudinally, it is thought th: lercrage for cracking it across, just as a long stick is $n$ broken than a very short one. Altogether a number of alements exist, which make tho question a very difficult on one given plate it may be that the total stored-up work in e a fair measure of the injury done, but how are we to cor plates of different dimensions?

I have suggested as a check on the perforation standar diriding tho stored-up work in the blow by the number of $t$ plate struck, wo have the shock per ton of plate. This shown in particular cases to be as grossly wrong as the I standard, but, depending on rather opposite conditions, it $m$ a check on it.2

To apply it to the examples giren on the table. The 3 at Shoebaryness was fired on July 21st, 1830, at a steel-f: 18 inches thick. The shot had a calculaled penetration of 1 and 12,980 foot-tons energy. The plate weighed about 24 to the blow was 541 foot-tons per ton of metal. Tho effect slight, the shot breaking up badly. At Spezin, in Novembe compound plates weighed about $31 \cdot 5$ tons, and the heavie:

1 The perforating equation of tho drop is then WII $=\pi \mathrm{D} \times t^{2} \times \mathrm{K}$, weight, If height of fall, D diametcr of bullet pungh, $t$ the thickness of $s h$ and $h$ coms cunstant. We hare just used it with $H$ and $D$ rarging, but $D$ with any pair of terms rariable aceording to what may be required. 'Tl out rery fairly correctly it wo rary $I f$ and $t$, and keep the other terms ec is, if wo try what thickness the same bullet perforates at different hei, $\mathrm{ms}$ be altered, and I hare tried the effect of loose weight on it with Captain Palliscr's jacket moring formard on his shot on impact. This glas balls in a groore, illustrates curiously the different effects of the reting loosely on each other, or, on the other hand, rireted together.

2 The shock is probably transmitted radially from the point of impa possibly the action might be inrestigated on a small scale by firing ste discs of steel and chilled iron, arranged in series, ono series of dises of $r$ another with rarsing thichness, and so on.

Since writing this paper and getting the proofs in type I hare receir the kindness of the German Attaché, a report of the IIagdeburg crp which I had referred, by which it appears that the striking encrgy per I is used as a measure of the shock on chilled iron. On this occasior ohilled shield was broken, but the pieces still held together after threc 12.inch steel projectiles weighing 931 lb3., with a relocity of abuut 1,4 bad borne a total sluck of $43,49 \bar{j}$ foot-tons, or 914.8 foot-tons per ton $c$ 
the second blow, the previous one having been 654 foc ton of metal. The two together then make 1,700 foot-tons metal. At Ochta the steel plate was broken with a blow of tons per ton of metal. The plate tried by the Rogal En Angust last at Shoeburyness probably weighed abont 10.5 a blow of 30,000 foot-tons then implies a shock of 2,857 for ton of metal, that is, four times as heavy a shock as any s at Ochta on a plate of the samo thickness. This was bor breaking the plate asunder or penetrating it. Unquestions the Engineers' Shoeburyness shield is a wonderfully good co by whatever standard it may be judged.

Following on from this, wo come to the question of With hard armour they break up, unless of very excelles Their effect must therefore greatly depend on their power together. Steel, therefore, ought in the long ran to beat $\mathrm{cl}$ I would point out that, in this country, our experiments made on softer armour than we may expect to meet for $t$ Even our compound plates are softer than the sleel armon Schneider, and much softer than Grüson's chilled iron. mean that the steel face is softer than that of Scluneider the other hand, the surface is harder, but the plate itself i the sense in which I have ased the word, that is, it is moro punch a hole in it. At. Shoeburyness, discs have occasic torn out of componnd plates, and clilled shot bave got $t$ completely through them. 'I am very much mistaken if $t h$ done with Schneider's or Grüson's armour. Hence it fol the comparative softness of our hard armour, that in this , see efforts made to punch hard armour, which I venture to have no future, and we have clung longer to chilled shot $t$ advisable. Sir IVilliam Palliser, in his improved shot, so element of reduced diameter is concerned, contemplated hole, and actaally did so, in a compound plate. Sir F. Ab carrying fire in a steel shell through armour is only applica armour, and it has, I think, no future on that account. ] in this form, or indeed in any forra, is so harmfal tha recognize the fact that armour will be made hard enough it; and it may be questioned whether the successful result: ing achieved by Krapp and ourselves aro not rather cal mislead us if we are not on our guard.

I would suggest, then, that the development of steel shot ing need in this country. A Commission was sent recen American Government to inquire into the manufacture of jectiles in Europe, and they concluded that England was Continent in this matter. The excellence of the Terre jectile fired at Spezia argues that a very high standare attained in France, even on the gigantic scale of a shot of calibre, woighing 2,000 lbs. In this country it is comp makers shriuk from submitting steel projectiles much orer 
turers naturally shrink from being judged on the merit unproved quality, and they could hardly bo expected to ur enormons outlay for plates necessary to investigate tl thoroughly. It seems most desirable, then, that any availa left from experiments should be devoted to the proof of proje uitted by manufacturers, not as "champion" shot on w stake their reputation, but as " pioneer" shot whose indivic jence is not the question, but rather the lesson they teach effect of ccrtain manufacturing processes. Again, one may grudge the loss of the experience that might be obtained if were substituted for the chilled iron ones at present employ Admiralty proof of plates. No doubt, such a substitution is matter. Until first sufficiently tested to insure against its $\mathbf{r}_{1}$ plate could hardly be attacked by shot of an experimental With this reserve, however, steel shot might, perhaps, be introduced, and as their quality becomes known they mig] chilled projectiles.

Finally, experiments against really hard armour appear to $l$ needed in this country. Neither Selneider's steel nor Grüsor iron have ever been tried by us. It may be perhaps consid foreign experiments hare settled the question in a measure $f_{f}$ we are satisfied with the comparison of our steel-faced arr that of Schneider at Spezia and at Ochta, and that we have as to its employment for our own ships. This, however, i: side of the question. We need knowledge as to the beharic projectiles in war against the armour employed by foreigr France has the most formidable Navy, and France largely Schneider's steel, against which our Service projectiles h: been tried at home or abroad. As to forts, the existence of $c$ depends on the possibility of vessels attacking them, an withont exception Grüson's chilled armour is employed abr heve never fired at it. Probably not six Officers in this con: ever seen chilled iron fired at. There is some reason to our chilled projectiles are unsuitable ones to attack it. Krupp attacked a chilled shield made to represent Grüss chilled shot. He wished it to be beaten by a wrought-iron his own. In a few rounds he was disappointed at the effect shot and replaced them by steel ones, which, in a measure, chilled iron.

In 1882 I believe the French made some experiment. chilled iron shields for inland fortifications. They had adop: but they found the effect of steel shot so much greater tha chilled shot against chilled iron that they rejected this ma inland works. At Magdeburg the chilled iron shield wa by the blows of steel shot. The behaviour of the 1 chilled shot at Spezia argues more tenacity though greater than ours. It may be questioned whether our chilled 


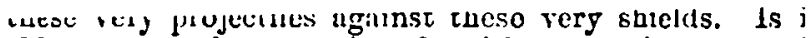
able to urge the necessity of making experiments agai chilled irou shicld in this country? This rould exe1 fullest extent the value of our Servico shot agninst really as $n$ general question. Besides which the nctual structur are formidable enough to make it desirable to know how with them in particular. They are not costly, and lo: lave saffered fundamentul fracture they would be arailal powers of our shot to hold together on impact against he

The three fentures, then, on which I wish to lay st: the need of a better system of estimating effects of arti nrmour; 2nd, the need for developing tho manufacture 0 : tiles in this country; and $3 \mathrm{rd}$, the necessity of ma Grüson's or other very hard armour in this country.

I hope it will not be understood that $I$ am urging the by any means gonernlly behind other nations in the matt and armour. Wre alone have mado 100-ton guns, and o armour is anricalled. In the most important experiments Powers English matériel takes a prominent place. Ner can by no means afford to shut our eyes to tho elements may bo reak, and in which foreign Powers may bo advantage over us.

TABLE shoving that in recent experinents shot have been mo compound plates according to their calculated poucers $c$ (vide Columns 5 and 6), not according to their smashidi uhich 9 is suggested as a moasure.

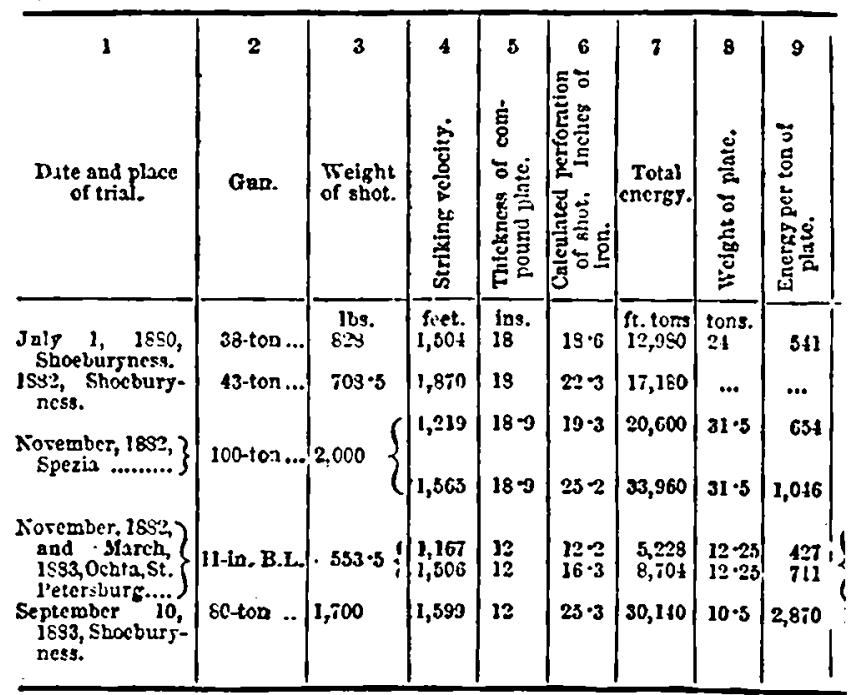


burg the compound targets lad only a few, and they came to pieces; where: other experiment at Slooburgness a fer bolts mero quite sufficient to hold $t$ up. In Itals and Russia it was remarbed that though the compound targ to picees, they fell in large fragments. I mould suggest that if the Englis! had been supplied with a suffeient number of bolt s:to beep them up at Spe ot St. Petersburg they would probably hare been initially reakened, bec increased number of bolt-holes takes away considerably from the strength $c$ or steel-faced target. It would appear that sometimes a large number of $t$ required, but not alwass; the large number apparently being necessary w backing is not hard, but comparatircly soft and yiclding. So far as ? eridence before us, compound armour secms best suited for use with hard such as granite, which can be used in the construction of forts, and it is $h$ applicable to ships. With regard to the size of stecl or compound targets, $j$ appear that there is a great adrantage in haring the indiridual plates dimensions, on account of what Captain Brome has urged that the an "work" in fuot-tons in the projectile on striking, per ton weight of target, is way to be taken into account in considering the resistance which can bo . witl nrought-iron plate 3 this consideration is of rery small inportance. appears that modern targets are rery thick, the joints consequently 6 through, or rery nearly so; whereas in the plate-upon-plate wrought-iron there are orerlaps like courses of bricks in a wall. It would therefore sc stcel or compound plates should be hearier than tho older oncs; this wo increase the total weight for a girce area protected, but the armour would 1 up of fewer parts. I beliere the present armour-plates are not mucl 30 tons in $\pi$ right ; if this could bo increased by alding to the superficial a not to the thickness, a greater resisting power would probably be obtained would inrolre estra expense and labour in manufacture, but it may be a d feature to consider for naral armour, whero the chicf object is to obtai nesisting porrer without increase of total weight. . No doubt manufacturer: object that their preser.t plant is not suffeient, but thes might be urged to i it and to produco plates of larger dimensions. Captain Browne has pointed great difference caused by hard and soft backing; it will probably bo rers. to arrive at any formula or calculation of the effects of fire vithout taking $t$ account carcfully. The complicated composition of the modern plates will tend to cause difficultics in making cstimations of resisting porer. 'The ] has surgested that experiments on a.small sealo might be uscful, as they wou to indicate the direction in which to procecd in making more reliable and ones, and this secms a sound method.

Admiral VESEY IIAsrutos : I slould like to say a few words, not with re the main point of the lecture, but to the conclusion which Captain Bron drakn. Erery naral Oficer will perfectly agrec that if what he says is cor shall go. into action with untried wcapons, that is to say, with guns and which wo do not know the effects. Nor, I think it is an important point th: we go into action we should know what the cffect of our sliot will be upon armour.

Aduimal SeLwrs: When, in 1870, at the Naral Architects, I dren ntten the subject of compound armour by asking them to consider tho analogy anril, I also preposed to use a pile-driring nachine for experiments, and $I_{a}$ to ace that Captain Orde Browne has carried that out so well. It is sub certain suriations wlijch liare to be considerod, but they are casils. climinate the results. For instance, the unsatisfactory results giren by the short $d_{t}$ will find are complicated by the element of time. Mr: Olirer Hrowne point in 1870 that when the elemont of time is ignored a great mauy new things $c$ -ner effects which you could not ureriously hare predicted. Well nor rogard to the compound armour, for that is unmistakably the armour of the unless anj other method cun gire less weight, for armourclad ships; I do : what will be done with regard to land batteries, that is a question for engin 


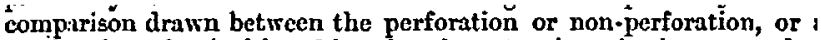
on the plate short of knocking the plates to pices in three rounds: Captain Browne. Now; I should like to know whether the conditi have ever been closely observed in compound armour. I say dist: good effects hare been produced in spite of the bad principle on whic been generally done. I see in Iate reports of the proceedings of Committee that Sir Joln Brown now appronches something more analogy of the anvil; that is to $8 a y$, he proposes to reduce the thickr plate in front, to fill the wrought-iron armour-plate with molten ste in a crystallized state, and thus to approach to the condition of the made up of a wrought-iron body, a cast-iron inside, and a steel pl the crystalline particles of the cast iron. In.this way, and in this be obtained that cone of dispersion which is the only means of expe of a shot if jou do not get complete perforation. You must do one either remore the mass of metal sideways or end ways before perforat or set up an action of.the particles of the soft metal which extingui of not very great length the whole force of impact. In the anvil done by a long and careful exporience leading forward to a perfect a will go at once to the condition of the anvil as our starting. poin armour-plates we shall go ahead much more rapidly and with muc] ence to back us than if $x e$ began by putting on a thick piece of which no anvil-makcr would erer resort to at all. He rould cxpect $t$ soft iron plate behind a thick steel plate it would be of no use, neithe steel plate if it were not accurately tempered on the surface. So ac be thit eren tempering an anvil the slightest degree out of the horizi it. If when a heated anvil is subjected to a doucho of water it horizontal it is spoiled; and this bears upon what mas said by $\mathbf{C e}$ about curred plates. If you try to harden the face of a curred plat methods it is almost impossible to harden all the surface at the $s$ : consequently there is a wrong disposition of material. But there which we can get this hardening withont the use of any water at not rery occult means; they hare been used for many centuries, and can be used again without much difleulty. The condition is this : steel surface, as hard as it can conreniently be made, for a rery ness, below that the less-hardened part. Then the blow must be di a comparatively softer material than the steel; that is found in $t$ particles, by means of which you must distribute.the blow. TI wrought iron which keeps such particles from lateral expansion. bchind that is an elastie backing, which will take up whatever blow through the crystalline particles, and which is used generally by blac form of a wooden block. We have that big wooden block in the for and as the ship is hollow it has a certain degree of elasticity, which the efforts to the whole strueture, this disperses the entire work don in a harmless way throughout the ship. You cannot, of course, de with granite backing, but, howerer, we hare little or nothing to do wi which batteries are built unless we are attacking them. In order fu gate the question. it: is absolutely necessary that experiments should made on Grïson's shicld of chilled cast-iron or.on steel armour, material should be neglected, that experiments should be carried ou and consistently, on a scale calculated to bring out steady results, but and impulses, for. experiments carried out in that way nerer prod result. We ought to begin at tho beginning, and then to go forward $u$. every result proposed. That can only be done by a continuous gorern you get a lot of different people coming in one after another you such experiments as Beaufoy's and. others have transmitted to pos deroted half a lifetime to it. All men gain by experience, and if a ne in, unless ho is willing to learn from the experience of the others 
ma... the mi!itars Serrice to carry out such experienents. It should not bo out of the question to associatc all tulent, no matter wlierc it concs $f$ What mas we expect if the analogs of the anril is carrich out in is inte glape of a conpound plato? Tre may expect tliat instead of cra. brenking up of plates there will be obtrined a complete resistance to the verr hearicst shot, und that br a comparatively light plate. And then as to I niu suro this is to be done by the method which $I$ liare pointed out. I thi berrun on a good path. Fou hare abandoned the idea of perforation in and sou are beginning to ece that bj proper adnptation of material sou complete resistunce. Now we hare to go forward, and I think that manchine is a splendid cabinet illustration. I should like to sec that $c$ : juto a large machine, such us a pair of slieer legs, and then we inight from each of thuse experiments to the rcalt that thes point to with slot and armour-plate. Hut the expensive form of begiuning with a ad cnding with pilc-driring machines is one which I du not think mar will cncourage. "Captain Browne las contributed inost excellent w hnowledge of this subject. I onls trust that as the thing is carried of will be kept informed, becaupe, unless we know more about it than we de wi are certaivly going with our lands ticd aidd our cyes blinded into $t l$ Thut should bo aroided by erexy possiblo means, and I am sure this Inst give through its lectures more intcresting and lecful information th obtained in any other was on such technical subjects as aro necessary t stood in order to the lessening the cost of eliciency during war, an jucreasing the duration of peace.

Colonel Sir Chables Nuasst, R.E.: I did not intend to offer any the neeting, but I should like to say a few words in reply to what $\mathbf{A d m}$ lito just suid. I do not think the inference he has drawn as to our comm the plate and ending with the anril is quite correct. It appcars to ine watter of wrought-jron armour-plates at leust wo hare adranced rers pre in fact, looking at the experiments that have been made I do not thin huring begun from the egr, have got up to the full-grown bird, which 1 has said is the state as regunls armour-plates, unless wo had done mention also with respect to the action of the Government in this mat bulpy condition of things that Admiral Sclwyn alluded to-the Utopin - Is to a certain exteut gained, inasmuch as the present Ordnanec cor upun it a number of scientifio narial Officers, nud is associated with ono eminent ciril engineer, to whom Admiral Selwyn alluded, Mr. 13 another ciril cngmeer of equal repute, and tlics for the last three jear the opportunities of being concerned with or cognizant of such espcrime becn made on armour-plates, both wrought-iron and compound, and uls experiments as hare been made with projectiles and with the desi projectiles, and the materials of which they should bo made. Perla time at our disposal it is not wortl going much into detail, with tho singl of the anril, to which ddmiral Selwyn has attached so much weight. Ile followed out the amalogy of the ansil, or went on that principle, what wor It appears to me what rould happen roald be we should havo an armo unmanageable thickness and weight, because expericnce has shown $t$ compound armour-plate you cannot secure a good result without a certii of hard resisting surface. Experience has shown that from one-third to than oue-third is tho best condition of manufacture, that is to say, ratlie one-third of hard steel facc, perliaps rather more than one-third of w backs, and then the intermediato stecl between the two. With regard to questions which the lecturer put, I lare one or two words to otfer. I three fentures on which he wishes to lay stress are, "first, the necd. systcm of estimating effects of artillery on hard armonr." Is he saic nost difficult question, but it has not allogether escaped the attention of 
of. In the absence of such formula we know the effect of certain wrought iron, and re also know to a certain extent their effect- on cor and we are uble to sas within certain limits that so much compound ire so much wrought iron. 'Then, with regard to the eccond point--" dareloping the manufacture of steel projectiles in this countrs" - we : that gencrally the principle of attacking steel-faced armour is to maki projectilcs. Althongh steel projectiles for the medium calibre of hear: produced in this country (I mas remark that the manufacture of sten) purposes in rerr large quantitics is confined to perhaps threc or four $n$ -the Cammeli Company, Sir Joseph Whitworth, and one or tro a who hare recently coule into the market to compete). The manuf: largest stcel projectiles has been thoroughly unsatisfactory up to because the difficulties of tempering the largo maszes of suitable na great that ther, the manufucturers, have not succeded in derising an orercoming then. For mssclf I think there is a method by which mas be net; howeter, it is not in being set. 'Phen, with regard to " of making trial of Grüson's or other Fery hard armour in this country, doubt but that a trial is very desirable, but the fault docs not altoget this country. I recollicet not many years ago; when I was connected way with the armour of the country, haring many interriews with $G$ r and in the end offering to him to produce a section of armour for th competing with what we considered an equiralent of our own armour, was nerer accepted. With regard to Sclneider plates, ke hare no in least in my recollection.

JIr. WLLter Broirie, M.I.C.E. : Being an engincer, and not $t$ I should not hare ventured to intrude upon the meeting if the discuss taken the military side of the question'; but as Admiral Selron forward the illustration of the anril, which is an enginecr's imples perhaps be allowed to sas a rord. It appears to me, in the illustr: giren, he has forgotten this point-that you nerer allempt to pierce a. ptrike an anvil with a lammer, and the only danger is that jou may cr across by tlic mere force of the blow. That is not the sort of danger guard ngainst in an armour-plate. Looking at the way in nhich the 1 plates are shomn in the diagrams to haro been fractured, I belicre thes question as to the mode in which it has been brought about. The hea las becn wedged into the face of the plate, and that has produced a $f$ radially outwards round the head, therebs producing a zone of highl: metal round the shot. The squeezing outrards of this compressc cracked the plate, either in rarlial or circular lines round it, as the cas look upon the ring crack, seen round the ghot in Fig. 3, as representi the outer circumference of that ring of hard metal. Exactly the say been prored experimentally to takc place in the ordinary punching 0 well-known erics of experiments by M. Barba at Toulon. He foun ndrantage aroso bs drilling out a thin ring of metal round an ordin hole before the riret was put in, and thus getting rid of the ring of hare metal. ${ }^{1}$ Looked at, then, from the point of ricw of the attacking part: me that our object eliould be to produce a shot which shall be sufficii to get into the plate and stop there, and at the same time sball have $t$ power of equeczing the metal outwards in all directions. In fact, $J$ broken up by a medging action, and the object should be to find the $n$ form of redge. Of course, the more taper a wedge is the more effe

1 It is well known that rireted plates, especinlly of hard iron, liare dency to crack along the line of rivet-holes, and from them to the edgo which scems strictly conformable to that of the stecl plates here consic be due to the same cause, namely, compresion and fiow of metal round 
remored for a given deptl of penetration, and the less the amount of round the shot. From that point of view you want to have your as possible: and I would suggest that the object of ans experiônent or shonld be to find out a shot which combines in the highest degree the linties $\rightarrow$ that is to sar, which has a point sharp enough to wedgo itsc into the metal, and then is large enough in diameter to produce mount of compression outwards in all directions.

The Cramsix : I would like to ask Captain Browne one or two q mard to his paper; and I may premise by saying, as Captain $1 I_{\text {; }}$ ddmiral Seliryn hare pointed out, that this question is far more impo Nary than it is for the land serrice. The ddmiralty, when they decide of ehip required, give certain conditions to the constructors; they say $t$ be of such and such a size. The constructor has to diride his weights partly in armour, partly in guns, partly in mexhinery, in coal storage and whaterer is taken off the one can be put on to the other; the cons we can reduce our protecting armour in reight we can put that amo guns, and thereby increase the efficiency of the slip. The weight $t$ is really the firgt consideration, or the main question in man-of-war, With regard to the diagram relating to the Shocburyness trials, Captain it is established that the best thickness for the wood between the two a is somewhere about 5 inches. I would ask whether that is realls an.estr and if that answers in all cases? For instance, supposing we hare $1.1 \mathrm{i}$ in the tro plates, one 6 inches and the otber 8 inclres, does that in good? Say, with different thickness of plates, different distribution of plates, and different sizes of projectiles fired. Captain Browne also "Shannon" trial, where he says, "Shells hare broken up instead of bu the plates at which they were fired, and the result has been but smal that is rather a mistake; because, if I recollect right, the report was, $t$ which broke up were "very effectire." What you want is to get done inside the ship. In the cases referred to, the sliell broke up on plating, and the powder was ignited inside when unconfined by the act and probably incendiary power was more dereloped in that way than had actually burst. I do not think, therefore, he is quite right in his there. With regard to the method of bolting the plates on, he gare us of bolts, but he did not gire us how the different plates were secured to My impression is that compound plates are bolfed on by serews from $t$ way into the metal, whereas steel plates are fastened by the old sjstem , pletely through, and nuts. Captain Browne has giren us these cor. special attention: he has put the formula for calculating effects first, a description of the projectile after it. In my view of the casc, the pri the first importance, because what is it that we really want to obtain? want merely to punch a hole tlirough a ship's side, and then for a solid go through to the other side. What we want to get at is something through the first side, then burst or break up into numerous pieces greatest possiblo amount of damage to guns and men inside. IIe says w to Professor dbel's riew that wo propose to get a shell that will go thrc and burst inside, "Sir Frederick Abel's idea of carrging fire in a stecl sl armour is only applicable to soft armour, and it las, I think, no fut account." I must say it not only has no future, but it lras nerer had think there are but feir cases on record in which shell hare really pas. armour-plates, and then burst inside; when they hare burst or bre alwass been in the ship's side or armour itself, and tho burst has not bec ship. No doubt, that. would be a great object to attain, but I rery mu it is not in the future. As to the method employed by the Admiralty $f$ of plates, the Admiralty proof of plate- is not made to discoser the perf the armour, but it is a standard trial of the ralue of the plates for actu Thee plates aro by experiment required to offer a certain amount of res 
ngo, when I was frst connected with the trials of nrmour.plates and gu to try our armour-plates with cast.iron round shot. We moored a gu yards from the ship's side on which the plates were bolted, fired frem the plate, and frequently obtained rery different results from the sam same plate. 'This was benildering, and it danned upion Captain $H_{\text {, }}$ Captain of the "Frcellent," that it must be something in the shot, w1 different degrecs of hardness, and I beliere he proposed tiie first steel st: crer made, and it was rery remarkable to sce the difference betree of roued stecl shot and the old cast-iron shot. That bring 3 us to the sideration, which is, that it is our duty to work out the question of pro whether they shill be chilled iron or stecl ; . and, whaterer they nas be institute a scries of experiments to test what is really not only the bes but the best form for the head of the shot for penctration. There is ar which we must nut lose eight of in armour-plutes and projectiles : perh Browno can gire us some idea of the difference in cost between a compo steel plate, and a soft iron plate. With regard to the laud ecrvice, if one enough another can be udded; but with regard to a suip it is a re thing. We must hare tho best, and as me shall require them in c numbers, expense unust to some extent be taken into cunsideration, but det riment of effieiency.

Captain Oroe Browse, in reply: With regard to what Captain ohserves, I suppose it cume to this, that the plates, while they full to piec thcir not having suficient bolte, had a ccrtum adrautago in the fact th: hare at all events split into fewer pieces. In taking into account the disa their not bolding up ugainst the backing, fou should reckon that tber gain in having fener bolis as regards the actual craching. Captain $\mathrm{MIa}$ preriously suggested this to me, and I renember I took up the tro crucks and of bolis and he]d them against tbe window to gee whether $t$ ] which run through this plate agreed at all nith the tolt-holes, and $\mathrm{J}$ that they do appear to in so; therefore, I think there is no doubt that able not to have nore bolis than is necrsiary absolutely to hald a plate regard to the ships, I did not quite understand what Captain Maclinlay lurger p'ates for ships or fewer bolts.

Cuptuin II ACKisiar: Simply that if the plate is rerg large tho amot per ton of pilate nould be rather less.

Cnptain Onde Brourse : Of course the question of area has to be and in ans inrestigution made it rould bo rers necessary to tey that from the question of depth or thickness of plate. The great point is $t_{1}$ one rariable at a time, and keep all the other conditions fised. I shou ecries discs of steel or chilled iron on a small gcale were fired at fon wo it worked. There must be come limit as to the way in wiich tive area cracking by the sliot. Aduniral Selugn eridently has had more experi, matter of drop than most people. and I am rery nuch obligel for wh It is just the small heighits where you have the dificulty. I believe if 1 of the $f$-ineh and inch bullets taken the $\frac{f-i n c h}{\text { and }}$ the inch, and so $d$ t-inch from a greater height than belonged to the 1 -inch, you would hav law cone out more accurately. I dicl not know that $A d$ mirsl Sel wrm had 1 of dropping weights to illustrate pusching before; if I had I should tioncd it. It is, lowerer, really an obvious thing to do. With reg question of the anril, it is not quite the same thing to take the blow of $t$ and to fire nt it. If an anril is to be cinsidered a satisfactory achiercm we want, is not there ang way in which jou could test it? Does Adm: think that we could fire a steel bullet at an anvil with good results?

Admiral Selwrx : I mado use of the last record of thic Ordnanco Co show that Sir Thomas Brown is making a precisely similat arrangement.

Cuptain Onde Buowse: Sir Jobn Jrown mines armour with a rulled plate on the outside. Ile is then perfectly certain of his cor 
bein a successful pattern of plate there ought to be some means of anvil in tbe same way: as the plate.

Admiral SeLTry : The impact is tho same, whether produced by gu ny other force.

Captain ORDE Browre: There ought to bo some relation of weight, course, the anvil mass is enormous as compared with any blow.

Admiral SeLwrs: The mass is as regards the whole ship.

Captain ORDE Browse: If you take the question of the hollowness

is not the blow almost too local? An anril cannot possibly jield locally

ddmiral SeLwry : Oh, yes, it does.

Captain ORDE BROWXE: I think practically it amounts to this, that th some way of putting the anvil on fair terms of comparison before one simit the application.

Admiral SELWYN: The latest and most successful experiments hare on those lines, and the more nearly those conditions are approached the steel plate acts.

Captain ORDE BRowre: With regard to what Sir Charles Nugent sai like it to be understood at once that my ohject is not in any way to poir tine authorities hare gone awkwardly to work. I am only trying to exectly where we stand at this minute. Take, for ex:mple, the punching. think one may consider that the calculations for punching, considering 1 stences under which they are made, aro as accurate as you can expect tho calculations to be. But the same thing is wanted to a critain extent armour, and I think it requires to bo recognized. Tou remember in spea unrenconableness of applying calculations to hard armour that I took a two sbots stand at a level as regards punching, and jet one had three atored-up work of the other. It is monstrous to suppose where no hole all that these two stand on a lerel. I was on one occasion beforc a taking a case of that sort, and I was told that no one who had any knomle apply that sort of thing to hard armour, but Iooking at that table beft recent experiments, while the circumstances are such that they do not any gross mistake, yet the inaccuracy appears in degree. For crar people are under the impression that the O.hta trial was at least as seri Spezia, jet there is grare reason to doubt it.

Sir CuakLes Nraesp: I had no intention of being the champic anthorities at all; but I thought perhaps an inference might have been $d$. what Captain Browne had said that nothing was being done.

Captain Orde Browxe: I do not think Sir Charles Nugent ment Hadfield among the names of the makers.

Sir Charles .Ncgest : I did not, but I was acquainted mith Iradfel ments.

Captain ORDE Browxe : With regard to those makers, Sir Charles $\mathrm{N}_{\mathrm{I}}$ that they want to make small shot, that they feel the difficulty of making shot of 17 inches diameter and 2,000 lbs. rreight. Sir Joseph Whitworth done it successfull 5 , and if that is the case, is not it a rers serious thing te the Terre Noire Company hate done so, and that Krupp can produce 1 projectiles of a great deal better quality than we can in this country? being the case, considering the expense there is in dercloping the manuf stecl projectiles on account of the plates required to fire them at, might wished that they could feel their way into the proof plates at the dimira course I am awrare that the primary object of proring plates is to get nerertheless, I beliere that the proof has sometimes gone on considerably point of rejection. When that is the case I wish that steel projectiles co in, because if you could derelop them withont expense to the country it a great matter. I suggested that once, and I wis told that makers were rc making these shots, and I tried to point out that they wore rery shy of ma on which their reputation was to depend, but that they would be ready to 
plates to try them at. With regard to the 5 mehes of wood, $J$ be considered an absolute fired quantity, no matter on what scale you are $f$ this reason that it wants a certain amount of padding to prerent on fracturing the other, and 5 inches apparently has been found practice to do that. I think jou will find that two layers of 2 -inch plan rertically and the other horizontally, are now generally used, and are prerent the two pieces of metal from coming together, while at the sal do not gire room for the point of the shot to clear itself of the front coming to the second plate. With regard to the "Shannon" experime most destructive results for men may be caused by certain shell breaki "Shannon" experiment was an extraordinary one. "Tho effects insid shocking. Happily they were only on dummies. Shrapnel shell will very great number of pices from mere impact, but I am afraid that $i$ slioll merely breaks from impact it is apt to break in rery few picecs, a is the reason why it is desirable that the charge of powder should burst

Sir Crarles Negext: When you resort to steel rou do so wit obtaining a thinner eurelope of metal and a larger powder charge, and the impression that the tendency of the steel enrelope may be to open to burst into pieces.

Captain ORDE Browre: That brings me to another point with Krupp's experiments. . Sir Charles Nugent's staterient would show the make these steel shells rather with a riew to incendiary effect than effect. With regard to Sir Frederick $A$ bel's steel shell, there are stec hare been through a considerable thichness of metal and hare not br And in the experiments made at Shoeburyness now and then therc promise of the possibility of such a thing, but notbing that could 1 upon. I think thes hoped that that possibility might ripen into a $\mathrm{cc}$ sou could depend upon. I think, howerer, that there is no chance account of the soft arinour giring place to hard. 'The bolting of the $p$. case, both compound and steel, was so nearly the same that there was call attention to. With wrought-iron plates the bolts go through the stcel and stecl-faced that is not the case; in both of these the bolt is the back, cutering only to a certain deptl, for the reasou that you mus the continuity of the surface of the steel if you could possibly help brought these questions up in hope of calling attention to them. If ar could be said here would end, for example, in Grüson's plates being tri be very glad. I am rery glad to hear from Sir Charles Nugent that the offer to try them in England. It is important to know that he $h$ and did not accept it. If that is so, of courso we are not entirely to bls

The Charrusix: It only remains nor for me to return thanks to $C$ Browne for his very instructire lecture. 